\title{
Evaluation of Potato Varieties for their Suitability under Northern Telangana Agro Climatic Conditions
}

\author{
Preetham $^{1^{*}}$, Ashwini ${ }^{1}$ and Pavan $^{2}$ \\ ${ }^{1}$ Horticultural Research Station, Adilabad-504001 (SKLTSHU), Telangana State, India \\ ${ }^{2}$ Krishi Vignan Kendra, Adilabad (PJTSAU), India \\ *Corresponding author
}

\begin{abstract}
A B S T R A C T
Keywords

Potato, Promising varieties, Growth, Yield attributes, Yield, Grades

Article Info

Accepted:

04 March 2018

Available Online:

10 April 2018

An experiment was conducted to evaluate the performance of seven promising potato cultivars for growth, yield attributes, yield and grades under Northern Telangana Zone. The experiment was laid out in a randomized block design with three replications and seven treatments during rabi 2017-18 at Horticultural Research Station, Adilabad. There is significant variation among the varieties in the growth, yield attributes, yield and grades of potato. Highest per cent of plant emergence was reported in Kufri Chandramukhi and Kufri Jyothi (100\%). Kufri Surya reported maximum plant height at 30, 60 and 90 DAP (45.23, 70.76 and $65.33 \mathrm{~cm}$ respectively). Kufri Chipsona-3 and Kufri Badshah reported maximum number of branches per plant at 60 and 90 DAP. Maximum number of compound leaves per plant were produced by Kufri Chipsona-3 at 60 and 90 DAP. Kufri Surya reported maximum fresh weight of tuber per plant $(832 \mathrm{~g})$ and tuber yield (29.86 t/ha). The highest per cent of Grade-B tubers were produced by Kufri Surya followed by Kufri Chandramukhi, Kufri Khyati and Kufri Chipsona-3. The results of the study indicate that Kufri Surya, Kufri Khyati and Kufri Chipsona-3 have the potential to grow successfully in Northern Telangana Zone.
\end{abstract}

\section{Introduction}

Potato (Solanumn tuberosum) is one of the major non cereal food crops in the world, in the volume of world crops production it ranks fifth following sugarcane, maize, rice and wheat (FAOSTAT data 2014). India contributes $7.55 \%$ to the total world potato production. Potato is highly nutritious, easily digestible, wholesome food containing carbohydrates, proteins, minerals, vitamins and high quality dietary fibre. Potato contains substantial quantity of energy, edible protein-
$2.8 \mathrm{~g}$, starch-16.3 g, total sugar-0.6 g, crude fibre- $0.5 \mathrm{~g}$, carbohydrate-22.6 $\mathrm{g}$ and vitamin-C $25 \mathrm{mg}$ per $100 \mathrm{~g}$ fresh weight of tubers (Bhuwneshwari et al., 2013).

The productivity of potato in India is quite low $(183.3 \mathrm{q} / \mathrm{ha})$ as compared to that of Belgium (490 q/ha), New Zealand (450 q/ha), UK (397 $\mathrm{q} / \mathrm{ha}$ ) and USA (383 q/ha). India needs to extend potato cultivation to non-traditional areas for meeting hefty target of producing 125 million tonnes potatoes by 2050 (Singh et $a l ., 2014)$. In South India, it is mainly grown 
in Karnataka and parts of Southern Telangana (Indian Horticulture Database, NHB, 2013). Genetic makeup has great influence on yield and quality of potato tubers. Various varieties of potato having wide variation in their yield potential and quality attributes have been evolved (Marwaha et al., 2010). These varieties further show variation in their attributes under different agro climatic conditions. The influence of location and cultivars on quality of potato tubers have been reported by researchers (Uppal and Paul, 2001; Kumar et al., 2003).

Government of Telangana want selfsufficiency in vegetable production and started a programme ManaUru - ManaKuragayalu. In the Zonal Research and Extension Advisory meeting conducted at Hyderabad it was decided that the climate and soils of Adilabad are suitable for potato cultivation and wanted to promote the best variety and have crop colony of potato in Adilabad district. In view of this an experiment is initiated to test the performance of Seven promising varieties suitable for (Deccan plateau) at Adilabad which is a part of Northern Telangana Zone.

\section{Materials and Methods}

A field experiment was conducted at Horticultural Research Station, Adilabad during Rabi 2017-18. The experimental site is located in Northern Telangana Zone at an altitude of 264 meters above mean sea level on $79^{\circ} 56^{\prime} 03$ " E longitude and $19^{\circ} 08^{\prime} 09^{\prime \prime} \mathrm{N}$ latitude. The soil is sandy clay loam texture, slightly acidic (6.31), low in nitrogen, medium in phosphorous and high in potassium content. Seven elite varieties KufriChandramukhi, KufriBadshah, KufriPukhraj, KufriJyothi, KufriKhyati, Kufri Surya and Kufri Chipsona3 were procured from CPRI, Jalandar. The experiment was laid in randomized block design with three replications. Healthy, uniform sized tubers were planted at a spacing of $60 \times 30 \mathrm{~cm}$ on $6^{\text {th }}$ November, 2017 and the crop was harvested on $5^{\text {th }}$ February, 2018. $120-80-100 \mathrm{~kg} / \mathrm{ha}$ of nitrogen, phosphorous and potassium were provided with urea, di ammonium phosphate and muriate of potash. Full quantity of phosphorous, potassium and half dose of nitrogen were applied as basal in furrows at the time of planting, while the remaining quantity of nitrogen was applied in two split doses. $1^{\text {st }}$ at first earthen-up and $2^{\text {nd }}$ at second earthen-up (25 and 45 days after planting respectively).Recommended package of practices were followed, need based plant protection measures were taken up (spraying of Ridomil gold ( $2 \mathrm{~g} /$ lit water) to prevent infestation of late blight and Dimethoate (2.0 $\mathrm{ml})$ and Fipronil $(2.0 \mathrm{ml})$ per lit of water for control of sucking pest.

Five hills from each plot were randomly selected for data collection of plant height, number of branches per plant, number of compound leaves per plant, number of tubers per plant, fresh weight of tubers per plant. Plant height was measured from the base of the plant to the terminal bud at 30,60 and 90 DAP. Tubers collected from each plot (30 plants in $4.5 \mathrm{~m}^{2}$ ) were weighed in $\mathrm{kg}$ for yield determination. The weight obtained per $4.5 \mathrm{~m}^{2}$ was then converted to $\mathrm{kg}$ per hectare. Tubers collected from each plot were sorted and classified into three grades: Grade-C potatoes with a diameter less than $28 \mathrm{~mm}$, Grade-B potatoes with a diameter between 28 and 55 $\mathrm{mm}$ and Grade-A potatoes with a diameter greater than $55 \mathrm{~mm}$. Potatoes from each grade and plot were weighed $(\mathrm{Wg})$. Wt is the weight of all tubers from the same plot. To determine the percentage of potatoes of each grade with in a plot the following formula was used: $\%$ of potatoes of grade $\mathrm{M}=(\mathrm{Wg} \mathrm{M} / \mathrm{Wt}) \times 100 . \mathrm{M}=$ Grade A, B or C. For each plot, the sum of the percentages of all grades equals to 100 . The data recorded under the study were subjected to statistical analysis as per standard procedure as suggested by Panse and Sukhatme (1985). 


\section{Results and Discussion}

\section{Growth Parameters}

Plant emergence varied from 91.11 (KufriBadshah) to $100 \%$ (KufriChandramukhi and KufriJyothi). There is no significant difference in the percentage of plant emergence with regard to varieties. Statistical analysis indicates there is significant variation among the potato varieties in respect of plant height with advancement up-to 60 days after planting in early varieties KufriChandramukhi, KufriKhyati and Kufri Surya and up-to 90Days after planting in medium duration varieties KufriPukhraj, KufriJyothi and Kufri Chipsona-3and late variety KufriBadshah (Table 1).

Kufri Surya reported significantly higher plant height $(45.23 \mathrm{~cm})$ over other varieties but was at par with KufriKhyati and KufriBadshah at 30DAP reported significant higher plant height $(70.76 \mathrm{~cm})$ at $60 \mathrm{DAP}$ and reported maximum plant height $(65.33 \mathrm{~cm})$ at 90 DAP but it was at par with KufriBadshah, Kufri Chipsona-3.

The variations in plant height among the different potato cultivars may be due to genetic and inherent characters of cultivars of potato which is in accordance with the findings of Kumar et al., 2008 and Bhuwneshwari et al., 2013.

Kufri Chipsona-3 reported maximum number of branches per plant at 60 days after planting but it was at par with KufriBadshah. KufriBadshah reported maximum number of branches per plant at 90 DAP and was at par with Kufri Chipsona-3, Kufri Surya and KufriJyothi. Varieties did not differ in the number of compound leaves at 30 DAP. Kufri Chipsona-3 reported significantly higher number of compound leaves (53.13 and 76.47) at 60 and 90 DAP but was at par with
KufriBadshah (Table 1). The variations in number of branches per plant and number of compound leaves per plant among the different potato cultivars may be due to different genetic make-up and better adoptability to prevailing environment conditions. Similar results were reported by Mehta (1987), Kumar et al., 2008, Bhuwneshwari et al., 2013 and Jatav et al., 2017.

\section{Yield attributes}

Significant differences in the number of tubers per plant were noticed among the varieties. Kufri Chipsona-3 and KufriBadshah reported significantly higher number of tubers per plant (19.53 and 17.33). There is no significance difference between the other varieties Kufri Surya, KufriChandramukhi, KufriKhyati, KufriPukraj and KufriJyothi (Table 2). Significant variations were observed in tuber weight per plant among the varieties. The average weight of tuber per plant ranged from 495 to $832 \mathrm{~g}$.

Kufri Surya reported maximum fresh weight of tubers per plant $(0.832 \mathrm{~kg})$ which was at par with KufriKhyati, KufriPukhraj and KufriBadshah. Variations among different varieties in regard to number of tubers per plant and fresh weight of tubers per plant may be due to genetic differences or agro ecological conditions.

\section{Yield}

Significant variations in the yield of tuber per hectare were observed among the varieties investigated. Kufri Surya reported significantly higher tuber yield per plot $(13.451 \mathrm{~kg})$ and tuber yield per hectare $(29.86$ t) which was at par with KufriKhyati and Kufri Chipsona-3 (Table 2). KufriJyothi reported least tuber yield per plot $(8.832 \mathrm{~kg})$ and tuber yield per hectare (19.627 t/ha). 
Table.1 Performance of promising potato varieties on different growth parameters during rabi season

\begin{tabular}{|c|c|c|c|c|c|c|c|c|c|c|}
\hline & \multirow[t]{2}{*}{ Variety } & \multirow{2}{*}{$\begin{array}{c}\text { Germi } \\
\text { nation } \\
\%\end{array}$} & \multicolumn{3}{|c|}{ Plant height (cm) } & \multicolumn{2}{|c|}{$\begin{array}{c}\text { No. of } \\
\text { branches/plant }\end{array}$} & \multicolumn{3}{|c|}{$\begin{array}{c}\text { No. of compound } \\
\text { leaves/plant }\end{array}$} \\
\hline & & & $\begin{array}{c}30 \\
\text { DAP }\end{array}$ & $\begin{array}{c}60 \\
\text { DAP }\end{array}$ & $\begin{array}{c}90 \\
\text { DAP }\end{array}$ & $\begin{array}{c}60 \\
\text { DAP }\end{array}$ & $\begin{array}{c}90 \\
\text { DAP }\end{array}$ & $\begin{array}{c}30 \\
\text { DAP }\end{array}$ & $\begin{array}{c}60 \\
\text { DAP }\end{array}$ & $\begin{array}{c}90 \\
\text { DAP }\end{array}$ \\
\hline 1 & KufriChandramukhi & 100.00 & 38.95 & 54.13 & 53.49 & 3.00 & 4.73 & 12.73 & 41.20 & 61.00 \\
\hline 2 & KufriBadshah & 91.11 & 41.57 & 61.88 & 64.09 & 5.80 & 7.80 & 11.07 & 48.60 & 72.30 \\
\hline 3 & KufriPukhraj & 98.89 & 37.11 & 44.91 & 48.43 & 1.67 & 4.40 & 10.07 & 25.67 & 57.87 \\
\hline 4 & KufriJyothi & 100.00 & 38.09 & 47.53 & 49.11 & 3.73 & 6.00 & 11.73 & 37.47 & 57.13 \\
\hline 5 & KufriKhyati & 97.78 & 43.40 & 57.42 & 55.21 & 5.13 & 5.60 & 10.80 & 39.13 & 66.93 \\
\hline 6 & Kufri Surya & 98.89 & 45.23 & 70.76 & 65.33 & 5.23 & 7.33 & 12.33 & 44.80 & 61.33 \\
\hline 7 & Kufri Chipsona-3 & 96.67 & 39.29 & 59.71 & 61.55 & 6.53 & 7.47 & 12.00 & 53.13 & 76.47 \\
\hline & $\mathrm{SE}(\mathrm{m})$ & 2.82 & 1.51 & 2.37 & 2.34 & 0.40 & 0.59 & 0.61 & 1.71 & 2.85 \\
\hline & C.D. & NS & 4.71 & 7.37 & 7.30 & 1.26 & 1.83 & NS & 5.32 & 8.88 \\
\hline
\end{tabular}

Table.2 Performance of promising potato varieties on yield attributes and yield during rabi season

\begin{tabular}{|r|l|c|c|c|c|}
\hline \multicolumn{1}{|c|}{ Variety } & $\begin{array}{c}\text { No. of } \\
\text { tubers/plant }\end{array}$ & $\begin{array}{c}\text { Fresh weight of } \\
\text { tubers/plant }(\mathbf{k g})\end{array}$ & $\begin{array}{c}\text { Tulber } \\
\text { yield/plot (kg) }\end{array}$ & $\begin{array}{c}\text { Tuber yield } \\
\text { (t/ha) }\end{array}$ \\
\hline $\mathbf{1}$ & KufriChandramukhi & 14.13 & 0.672 & 10.327 & 22.947 \\
\hline $\mathbf{2}$ & KufriBadshah & 17.33 & 0.718 & 10.909 & 24.243 \\
\hline $\mathbf{3}$ & KufriPukraj & 14.07 & 0.746 & 10.573 & 23.493 \\
\hline $\mathbf{4}$ & KufriJyothi & 13.73 & 0.495 & 8.832 & 19.627 \\
\hline $\mathbf{5}$ & KufriKhyati & 14.13 & 0.753 & 12.656 & 28.123 \\
\hline $\mathbf{6}$ & Kufri Surya & 14.60 & 0.832 & 13.451 & 29.86 \\
\hline $\mathbf{7}$ & Kufri Chipsona-3 & 19.53 & 0.616 & 11.791 & 26.200 \\
\hline & SE (m) & 0.91 & 0.05 & 0.543 & 1.206 \\
\hline
\end{tabular}

Table.3 Variety percentage by weight of different grades of tuber

\begin{tabular}{|l|l|c|c|c|}
\hline \multicolumn{1}{|c|}{ Variety } & \multicolumn{3}{c|}{ Percentage by Weight of Tubers (\%) } \\
\hline $\mathbf{1}$ & KufriChandramukhi & Grade-A & Grade-B & Grade-C \\
\hline $\mathbf{2}$ & KufriBadshah & 14.17 & 63.42 & 22.42 \\
\hline $\mathbf{3}$ & KufriPukraj & 16.17 & 57.47 & 26.36 \\
\hline $\mathbf{4}$ & KufriJyothi & 17.07 & 58.18 & 24.75 \\
\hline $\mathbf{5}$ & KufriKhyati & 20.78 & 45.40 & 33.82 \\
\hline $\mathbf{6}$ & Kufri Surya & 14.40 & 60.11 & 25.48 \\
\hline $\mathbf{7}$ & Kufri Chipsona-3 & 13.69 & 66.65 & 19.66 \\
\hline
\end{tabular}



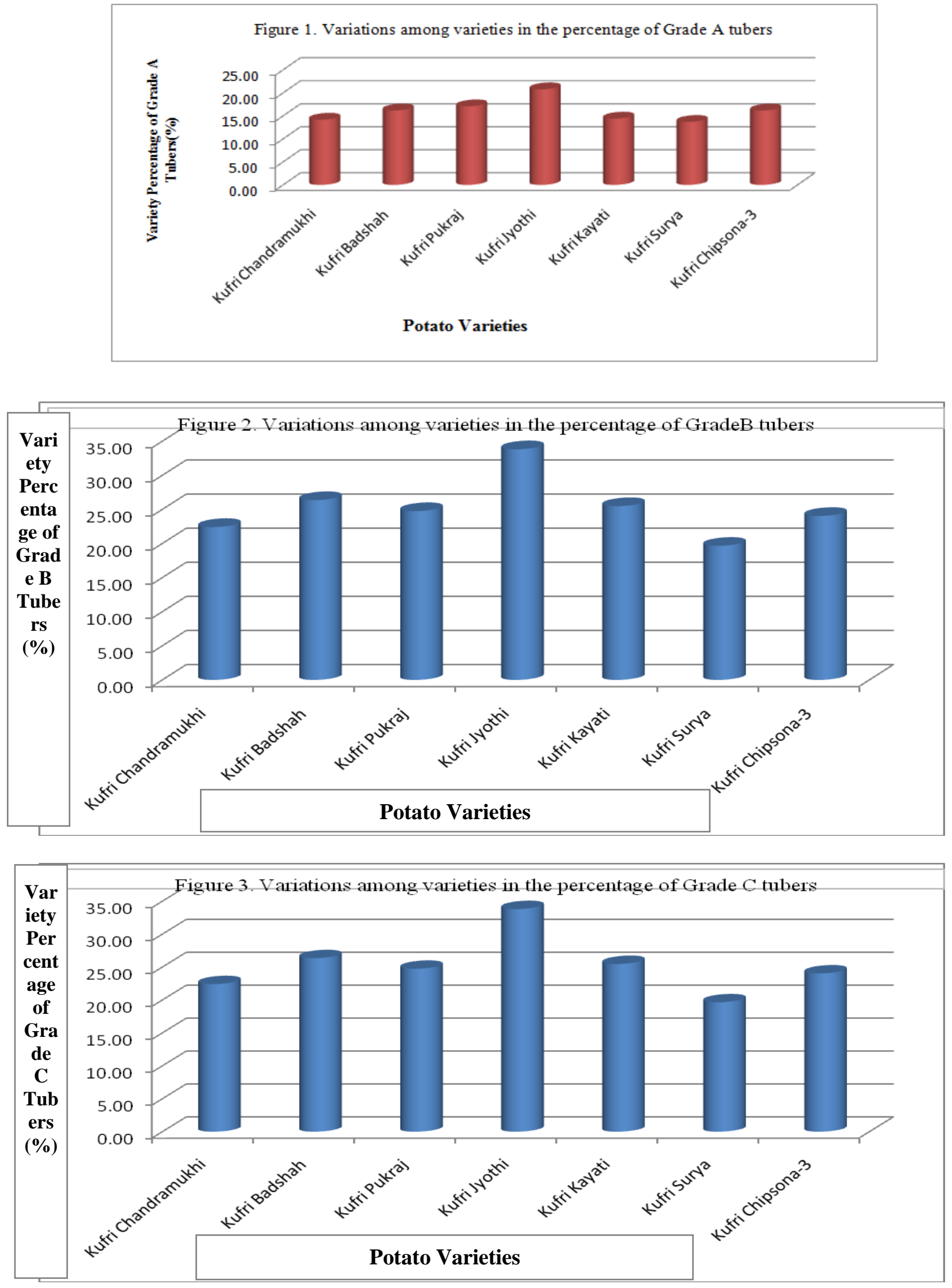
The results are in agreement with other researchers who investigated that tuber yield varies significantly with variety, location and genotypes $\mathrm{x}$ environment interaction (Elfinesh, 2008, Gebreselassie et al., 2016, Pandey et al., 2004 and Kumar et al., 2007)

\section{Grades of Tuber}

Medium size tubers (28-55 $\mathrm{mm}$ diameter) (Grade-B) are desirable for better storage. Significant variations were observed among the seven varieties tested in the number and production percentage of different grades of tubers (Table 3 ).

The highest percentage of Grade-A tubers was produced by KufriJyothi (Table 3 and Fig. 1). The percentage of Grade-B potatoes (Table 3 and Fig. 2) was higher in all the varieties than the percentage of Grade-A or Grade-C potatoes. The range of weight of Grade-B tubers was between 45.40 and 66.65 of total weight of all grades of same variety. The highest percentage of Grade-B tubers was produced by Kufri Surya followed by KufriChandramukhi, KufriKhyati and Kufri Chipsona-3. Highest percentage of Grade-C tubers was produced by KufriJyothi (Table 3 and Fig. 3) and lowest percentage of Grade-C tubers was produced by Kufri Surya. These differences in the percentage of different grades among the varieties might be due to genetic variations or adoptability of the variety to the climatic conditions of the experimental site.

Among the seven promising varieties tested at Horticultural Research Station, Adilabad, Kufri Surya produced the tallest plants, maximum fresh weight of tuber per plant, tuber yield per plot and tuber yield per hectare and it has produced greatest per cent of medium sized potatoes in comparison to other varieties. Kufri Chipsona-3 has produced more number of tubers per plant and on par yields with Kufri Surya and Khyati. The results of the study indicate that Kufri Surya, KufriKhyati and Kufri Chipsona-3 have the potential to grow successfully in Northern Telangana Zone.

\section{References}

Bhuwneshwari, Satish, Verma, K., Kamal Narayan and Paikra, M.S., 2013. Evaluation of processing potato genotypes for growth, yield and yield attributes under Chhattisgarh condition. The Asian J. Hort., 8 (1): 241-245.

Elfinesh, F., 2008. Processing quality of improved potato (Solanum tuberosum L.) varieties as influenced by growing environment, genotype and blanching. M. Sc. Thesis, School of Graduate Studies of Haramaya University, Ethiopia

FAOSTAT Data, 2014 Agricultural Data Provisional 2013 Production and Production Indices Data. Crop Primary. (http:/apps.fao.org/default.jsp)

Gebreselassie, H., Mohamed, W and Shimelis, B., 2016. Evaluation of potato (Solanum tuberosum L.) varieties foryield and yield components in Eastern Ethiopia, J. Bio. Agri. and Healthcare, 6(5):146-154.

Indian Horticulture Database, 2013. National Horticultural Board http://www.nhb.gov.in/area-pro/Indian Horticulture 2013.pdf

Jatav, A.S., Kushwah, S.S and Naruka, I.S, 2017. Performance of Potato Varieties for Growth, Yield, Quality and Economics under Different Levels of Nitrogen. Advances in Research 9(6):19

Kumar, D., R. Ezekiel and S.M.P. Khurana, 2003. Effect of location, season and cultivar on the processing quality of potatoes. J. Indian Potato Assoc., 30: 247-251. 
Kumar, Parveen, Pandey, S.K., Singh, S.V., Singh, B.P., Rawal, S. and Kumar, D. (2008). Evaluation of nutrient management for potato processing cultivars. Potato J., 35(1-2): 46-52.

Kumar, S., Khade, H.D., Dhokane, V.S., Bethere, A.G and Sharma A., 2007. Irradiation in combination with higher storage temperatures maintains chipmaking quality of potato. J. Food Sci., 72 (6): 402-406.

Marwaha, R.S., S.K. Pandey, D. Kumar, S.V. Singh and P. Kumar, 2010. Potato processing scenario in India: Industrial constraints, future projections, challenges ahead and remedies-A review. J. Food Sci. Technol., 47: 137156.

Mehta, A. 1987. Growth of potato varieties during autumn spring in Punjab, $J$.
Indian Potato Association 14(3-4): 129134.

Pandey, S.K., Singh, S.V., Kumar, P and Manivel, P., 2004. Sustaining potato chipping Industry from western and central Uttar Pradesh: Adoption of suitable varieties. Potato J., 31(3-4): 119-127

Panse, V.G. and Sukhatme, P.V. (1985) Statistical Methods for Agricultural Workers. Fourth Edition, Indian Council of Agricultural Research Publication New Delhi, 87-89.

Singh BP, Rana Rajesh $\mathrm{K}$ and Govindakrishnan PM (2014) Vision 2050. Central Potato Research Institute, Shimla $171001 \mathrm{HP}: \mathrm{x}+26 \mathrm{p}$

Uppal, D.S. and S.M.P. Khurana, 2001. Chipping performance of potato varieties grown at different locations. $J$. Indian Potato Assoc., 28: 233-236.

\section{How to cite this article:}

Preetham, Ashwini and Pavan. 2018. Evaluation of Potato Varieties for their Suitability under Northern Telangana Agro Climatic Conditions. Int.J.Curr.Microbiol.App.Sci. 7(04): 400-406. doi: https://doi.org/10.20546/ijcmas.2018.704.045 